sciendo Порівняльна професійна педагогіка 8(2)/2018 Comparative Professional Pedagogy 8(2)/2018

DOI: $10.2478 /$ rpp-2018-0014

Doctor of Science in Pedagogy, Full Professor, LARYSA LUKIANOVA Institute for Pedagogical Education and Adult Education of the National Academy of Pedagogical Sciences of Ukraine, Ukraine Address: 9 M. Berlynskyi St., Kyiv, 04060, Ukraine E-mail: larysa.lukianova@gmail.com

\title{
DEMAND AND SUPPLY ANALYSIS OF ADULT EDUCATION SERVICES IN UKRAINE IN THE CONTEXT OF FOREIGN SCHOLARS' VIEWS
}

\begin{abstract}
Social and economic transformations which are taking place in the Ukrainian society, the development of market relations, fast scientific and technical progress require the introduction of the model of the continuous knowledge upgrading that is necessary for the successful professional and personal development. The problem of educational needs is an interdisciplinary field which is defined by the complex of social and humanitarian sciences. The determining place among these sciences belongs to philosophy of education, sociology and pedagogy. The author is of the opinion that the investigation of educational needs of Ukrainian citizens will allow characterizing the educational situation in the country, substantiating the mechanisms of regulating separate subsystems of modern adult education and identifying some problems which hinder the development of this educational branch. There have been considered the questions of meeting the educational needs of the population as well as the peculiarities of forming the educational needs. In addition, the author's understanding of the term "educational needs" and their characteristic features have been offered in the paper. The article represents the results of investigating educational needs in one of Ukraine's regions, the purpose of which was to identify the requirement level of educational needs, to assess the quality of the provided educational services, to distinguish the motives of their use and the perspectives of their dissemination in the region.
\end{abstract}

Keywords: adult education, requirements, educational needs, demand, supply.

\section{INTRODUCTION}

The political, economic, social changes taking place in the Ukrainian society, globalization processes, the development of market relations, the acceleration of scientific and technological progress, the rapid processes that make information obsolete and the need for its updating, require constant training, retraining, and upskilling of a large number of people. Knowledge and relevant qualifications become the priority values in human life in the conditions of the information society.

According to G. Mazurkevich (2009), the key task of the modern society is the use of intellectual capital to find the ways to solve such problems as aging of the population, rising production costs, rapid technological development, migration processes, intercultural differences, and rapid aging of knowledge.

THE AIM OF THE STUDY

The paper aims to analyze demand and supply of adult education services in Ukraine in the context of foreign scholars' views. 
sciendo Порівняльна професійна педагогіка 8(2)/2018

Comparative Professional Pedagogy 8(2)/2018

\section{THEORETICAL FRAMEWORK AND RESEARCH METHODS}

It should be noted that the problem of educational needs is an interdisciplinary direction and is studied by the complex of sciences of the social and humanitarian cycle, among which the philosophy of education, sociology and pedagogy occupy a special place. The philosophical aspect of lifelong learning was presented in the scientific works by V. Andrushchenko, V. Kraevskyi, V. Kremen, A. Novikov, I. Ziaziun et al. The psychological and pedagogical substantiation of adult's educational needs was reflected in the writings of O. Anishchenko, S. Babushko, A. Daryniskyi, M. Gromkova, N. Nychkalo, S. Vershlovsky, O. Voliarska, S. Zmeyov; psychological aspects of professional formation, adaptation and self-actualization of personality were studied by D. Colb, P. Jarvis, R. Keog, A. Maslow, E. Pomytkin, K. Rogers, V. Rybalka, Z. Stanovskih et al. Contemporary Ukrainian and foreign sociologists R. Budon, J. Bellantine, J. Coleman, F. Filippov, D. Fitterman, J. Habermasand, L. Kogan, A. Osipov, M. Rutkevich made a significant contribution to the substantiation of the sociological approach in the content of educational needs.

The natural question arises: "Why is the problem of adult education becoming so urgent?" Firstly, as it is known, this problem is exacerbated in the crisis conditions of the society, when there is a change in the needs of consuming-motivational and valueregulatory mechanisms of educational activity, which initiates the activity of the subject, his ability to show intellectual and spiritual independence in conditions of disparate cultural landmarks and changing educational trends. Secondly, the importance of increasing the role of lifelong learning comes from the complexity of the social environment, which requires constant choice of decision. Therefore, the more information people will have, the higher the level of their education and the more conscious their decisions will be, which will be taken on the basis of their own knowledge and background. Thirdly, this is due to the objective need to constantly introduce new technologies that arise as a result of unceasing scientific and technological progress. Just to illustrate it, most recently computer literacy was an exception, now the use of a computer in professional and everyday life becomes common. Conversely, the lack of skills in using INTERNET or the inability to send e-mail can become a serious barrier to professional careers.

Research of educational needs of Ukrainian citizens as subjective characteristics representing objective conditions of their life will allow characterizing the educational situation in the country, justifying the regulation mechanisms of certain subsystems of modern adult education, identifying some problems that hinder the development of this educational branch. The need for such a study is explained by the need to resolve certain contradictions, in particular between the democratic transformations taking place in Ukraine, the development of market relations, the rise of political activity, the formation of civil society and the strengthening of the consumer focus of educational needs, and their orientation towards the professional growth while personal development remains without due attention.

Thus, study, systematization and analysis of educational needs will make it possible to understand the trends in adult education and to predict the vector of development of the adult education content in Ukraine.

The category "need", its classification and the question of the development of the person's educational needs have been reflected in the writings of Ukrainian and foreign researchers such as F. Kotler, E. Kudelina, L. Lipych, S. Mochernyi, R. Pushkar et al.

"Educational need" is directly related to the phenomenon of culture according to philosophers, psychologists and educators, and it becomes required for the transformation of natural instincts into potential opportunities. For example, according to G. Hegel, the 
difference between the needs of man and animal consists in the fact that the animal has a limited range of means and ways to meet their limited needs. A man proves their originality, first of all, by creating a variety of needs and means, and then distinguishing separate parts and parties in the particular need.

According to Ukrainian researchers, the need is a category that reflects the attitude of people, and, consequently, behavior, to the conditions of their livelihoods. The structure of needs is large enough. In addition to economic, there are a number of other needs cultural, political, ideological, national, etc. (Kryvenko et al., 2003, p. 110).

The potential of educational needs is also observed in the humanistic views by E. Fromm, who sees the anthropological value of this phenomenon in preserving the cultural dimension of human existence, the development of their abilities and the increase of opportunities in the process of self-cognition. According to E. Fromm (2010), in the process of realizing educational needs, a person creates new combinations of elements of experience, brings novelty into both his/her subjective and objective reality, structures new practices and more effective mechanisms of interaction with the environment of life.

According to the modern German philosopher J. Habermas (1993), educational needs and interests form the source of mankind's main aspirations, determinants of sociocultural and civilization specificity (pp. 228-238). According to N. Luman (2005), educational needs in the conditions of modern globalization processes are determined not so much by the lack or incompleteness of knowledge, but by the need to build effective social practices of self-organization.

Currently, educational needs are an instrument that forms a person as an active subject of reality. They precede creative searches; lay the foundations of value-normative systems, socio-cultural models. We share the view of D. Aleksandrov (2011) that in the new conditions, educational needs are aimed at mastering the technologies of knowledge generation, methods of processing information, symbolic communication as the influence of knowledge on the knowledge itself (p. 8). In the instrumental sense, the function of educational needs consists in the production of search and creative abilities of individuals, overcoming the limitations of historically formed forms of being.

Consequently, we understand the educational need as a state of the subject in the educational space, which is manifested both as the intention, determined by the disposition of the subject in the field of educational services, and as a subjective desire for knowledge, skills and abilities. Despite the variability, the "plasticity" determinants of human behavior, that is, the interdependence of needs, interests, motives, aspirations and their dense combination in a particular situation, the educational need is considered by us a decisive phenomenon that determines the quality of more complex educational orientations and interests (Aleksandrov, 2011, pp. 10-11).

According to F. Kotler (1999), the formation of educational needs and the level of their satisfaction are always influenced by a set of factors, in particular: demographic (population growth, age structure, educational level, geographical location); economic environment (distribution of income, prices); natural (reduction of natural resources, rising energy prices, growth of environmental pollution, state environmental protection); technical and technological (accelerating scientific and technological progress, endless possibilities); political (legislative); socio-cultural (p. 209).

At the personal level, the available need in education involves enriching the individual with new knowledge, defining professional and personal growth, enabling socialization, selfrealization, and also forms a way of life. At the group and societal levels, educational needs 
sciendo Порівняльна професійна педагогіка 8(2)/2018

Comparative Professional Pedagogy 8(2)/2018

fulfill the functions of social development of groups, communities, and society as a whole. Hence, the nature of educational needs plays a significant role in the process of selfaffirmation of man, provides a process of knowledge, promotes the mobilization of the will, defines the vector of target guidance, and forms a number of socially important qualities of the individual. This means that the formation of educational needs is a consequence of the development of basic, fundamental human needs, which should be considered as a single system, all elements of which are interconnected and mutually influential. Therefore, only through the influence on the entire system of adult needs the person's need for education can be intensified and directed. In the structure of human needs, the educational need is the closest to the cognitive needs and is its concrete expression.

According to experts, the world demand and educational services are increasing rapidly, especially in higher and postgraduate education. Most of all, this growth is inherent in dynamically developing countries, and their annual growth rate reaches $10-15 \%$.

In the context of our study, the idea that educational needs indirectly predetermine the development of continuous education, the formation of the subculture of a social group, the translation of cultural heritage and social experience of generations, the formation of the information space of society, the self-identification of social groups, the reproduction of social groups and the professional structure, adaptation of social groups, communities to changes in social conditions (Lapin, 2003, p. 68).

During the period from 2015 to 2017, we conducted the research aimed at studying the educational needs of the inhabitants of certain regions of Ukraine. In particular, we sought to find out the level of demand for educational services; evaluate their quality and formulate promising directions for the development of educational space in one region (in particular Zaporizhzhia oblast) in order to further develop a regional model for the development of adult education.

A special questionnaire was developed for the study, which took into account the peculiarities of the research subject and the socio-demographic structure of the region where the study was conducted.

The questionnaire had two blocks of questions in a total of 35. The first block contained 20 major questions that responded to the research objectives; the second sociodemographic block - 15 questions.

The total number of respondents who participated in the study was 400 people. The error laid down in the sample for a confidence interval of $95 \%$ does not exceed $5 \%$. The sample of respondents was unrepeatable, multi-stage, district, stratified, quota.

In particular, gender stratification made up $56.3 \%$ of women and $43.7 \%$ of men.

We have thoroughly defined the age composition of the respondents who participated in the study. As understanding the peculiarities of adult development, namely the periods and phases, tasks and transitional periods will help to better realize the motivation of adults to study, to see a coherent picture of the educational needs of adult learners (Marriam, \& Brockett, 2007). In general, the respondents from 16 to $60+$ years of old participated in the study.

Since the limits of article cannot allow covering the analysis of the results of all responses, only some of them will be revealed.

\section{RESULTS}

One of the most important ways to optimize adult education is to manage their motivation for learning, based on the results of scientific analysis and the laws of their personal development. According to scientists, the significance of the motivational sphere of the learning 
process is equivalent to the knowledge of the driving force behind this process. In general, the motivation of adults to study is the result of an understanding of their discrepancy between the level of available knowledge and knowledge required: a) for professional activity, b) for awareness of changes taking place in society, c) for awareness of personal changes (Y. Kuliutkin, L. Lesokhina, G. Sukhobska, S. Vershlovsky et al.). In essence, it emphasizes the ability of education to meet two groups of needs: in the physical and social existence (G. Dylichensky). Experiences of growing own opportunitiesare considered as the driving force of its activity (L. Antsyferova). Even in conditions of rather rigid external influences it is considered that the decision of an adult to study is the results of his/her free choice.

What motivates adults to learn? The need to study the motivation of adult learning is determined by many factors. The results of the study of motivation can be the starting point for creating the means for its formation, development or correction of the existing motivational sphere. This aspect is extremely important not only for adults, who are already learning, but also for potential students whose motivation has not yet been formed, or because of a combination of reasons it is at a low level.

So the first question of our questionnaire was related to the motives of learning. We invited respondents to name the most important ones for the reasons of their obtaining educational services and offered seven options for answers. The motivation of adult learning activities is heterogeneous, but can be reduced to three types: utilitarian (with leakages from a person's socio-occupational practice and based on the need to improve this practice), motivation for prestige (training increases the status, makes it possible to separate from the environment) and motivation, when knowledge becomes an end in itself (Kulyutkin, \& Sukhobskaya, 1972, pp. 63-67). Summing up the distribution of responses, we received the following picture: $77.7 \%$ of respondents have the most utilitarian motivation to study because they are studying for career growth, the opportunity to obtain a diploma or to change the profession or on the demand of the employer. Approximately the fourth part $-25.6 \%$ of respondents study because they want to increase their chances in the labor market, which will give them the opportunity to raise their status, that is, their motivation is for prestige. At the same time $8.6 \%$ of respondents indicated that the motive was knowledge for the sake of the knowledge (third type of motivation) (Fig. 1).

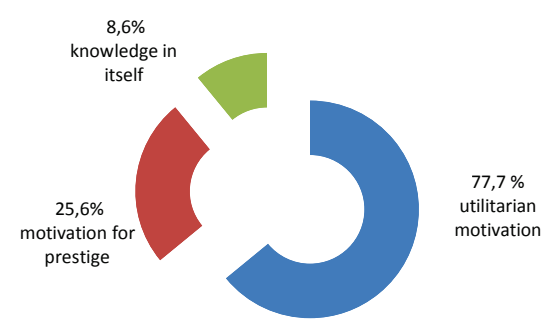

Fig. 1. Motives for learning. Typology of respondents' motives

Details of the motives for learning are reflected in Fig. 2, which also highlights the importance of utilitarian motivation. It can be seen that the largest number of respondents indicated that they needed knowledge for career growth $(46.7 \%)$, obtaining a diploma or certificate $(30.1 \%)$ and increasing chances in the labor market $(19.2 \%)$. 
sciendo Порівняльна професійна педагогіка 8(2)/2018

Comparative Professional Pedagogy 8(2)/2018

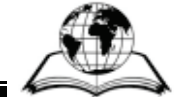

We were aware that quite often adult learners can personify several types, as well as switch from one type to another, depending on the situation, so that respondents had the opportunity to choose up to three variants of answers and thus the total the number of responses exceeded $100 \%$.

Today it is customary to distinguish three subsystems of adult education depending on the social and personal significance of educational needs and opportunities for their satisfaction: formal (implemented in educational institutions of different levels, as well as specialized programs offering technical and vocational training), informal (any educational activity, organized beyond the formal education that complements it and provides the acquisition of the skills and abilities necessary to adapt a person to modern society) and informal (unplanned, based on experience, incidental learning that occurs in the course of everyday life).

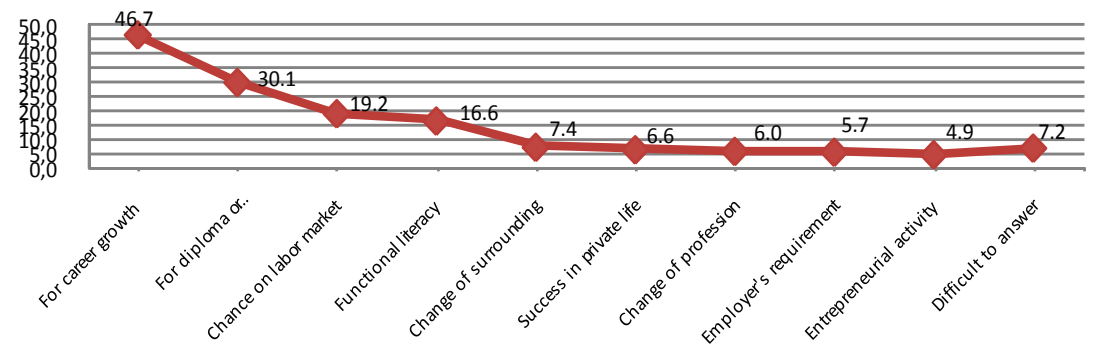

Fig. 2. Detailing of respondents' learning motives

In the developed world, informal education is now at the forefront. It was important for us to find out the attitude of our citizens towards these educational directions. With the view of this, we asked the respondents which of them they prefer. More than half of respondents reported that it is more acceptable to learn in the formal education system, $40.9 \%$ - indicated non-formal education, the rest were not determined. Thus, the answers to the attractiveness of the forms of learning were the expected ones, since the largest number of respondents $(38,8 \%)$ indicated that lectures are the most appropriate for them, namely, lectures are the main form of formal education.

To the question "Do you need to acquire knowledge", 4 variants of answers were submitted. The first one - "There is a desire, but I do not know where it can be done" was chosen by $61.6 \%$ of the young people, $50 \%$ of the middle-aged and $33.0 \%$ of the thirdaged. The second option - "Yes, there is a desire and I know how to study there", was supported by $28.8 \%$ of young people; $26.7 \%$ of the people in their middle age and $8.4 \%$ of the third age people. Moreover, $6.8 \%$ of young people; $13.3 \%$ of middle-aged people and $48 \%$ of third-year-olds do not have such a need. Part of the respondents could not determine the answer (Fig. 3).

Among the main disadvantages of adult education in the region, the respondents called a narrow range of proposals $(11.0 \%)$; outdated material and technical base $(12.5 \%)$. The barrier to learning is uncomfortable location of the institution $(6.8 \%)$, inconvenient time $(5 \%)$, lack of certification of the institution $(1.2 \%)$. However, in our opinion, there are such disadvantages as poor quality of educational services $(16.6 \%)$, incorrect teacher behavior $(8,0 \%)$ and high cost of education $(10.1 \%)$. 


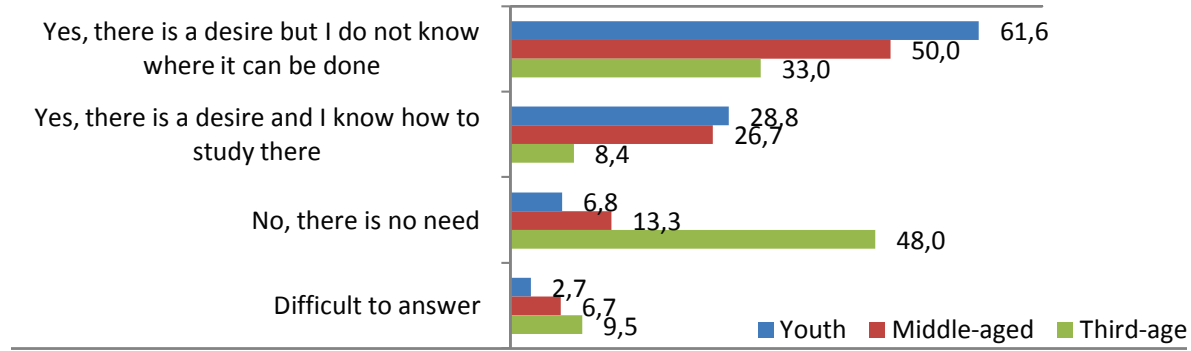

Fig. 3. The answers to the question "Do you need to acquire new knowledge?"

What exactly attracts respondents to the consumption of educational services? In the first place, the professionalism of teachers (34.9\%), the low cost of educational services $(14.2 \%)$. Unfortunately, only $2.2 \%$ of respondents appreciated the modern state of knowledge. More than half of respondents consider the level of awareness about providing educational services to be sufficient.

The presented data are the intermediate results of the started research on the educational needs of the adult population in different regions of Ukraine, which partly reflects the trends of educational needs of the inhabitants of the Zaporizhzhia region. At the same time, at this stage, we can emphasize that the attitude of adult Ukrainians to the need for lifelong learning is determined not only by the changes that take place in their personal lives, but also reflect the depth of awareness of the changes taking place in the country. The research will be continued.

\section{CONCLUSIONS}

In order for education to really fulfill the role of social regulator, particularly in the field of human needs, it should be man-centered. This means, firstly, that the content of modern education should include the problems associated with the study of man in all the dimensions, and secondly, the purpose and objectives of education should be oriented towards education as a multi-functional value, and thirdly, the active inclusion of personality is required in the cognitive process, which means, on the one hand, the study of the socio-psychological characteristics of this audience (in particular, the attitude to education, motivational factors, personal needs and characteristics, etc.), and, on the other, the application of such forms and methods of training in which the process of interiorization of the acquired knowledge is taking place as fast as possible.

Objective-subjective conditionality of an adult's attitude to education is the basis of a complex of measures aimed at forming his/her educational needs. This system of measures, on the one hand, should be based on the analysis of the connection of education with the most important aspects of the society's life, on the other hand, on the peculiarities of the status and position of an adult, his/her attitude to the outside world, himself/herself, and education. 


\section{REFERENCES}

1. Aleksandrov, D. V. (2011). Osvitni potreby naselennia v konteksti rozshyrennia informatsiinoho prostoru. Ukrainskyi sotsium, 1, 7-14.

2. From, E. (2010). Maty chy buty? Kyiv: Ukrainskyi pysmennyk

3. Khabermas, Yu. (1993). Piznannia ta interes, knyha z chytannia u filosofii. (T. 1-6). Knyha 6. Inozemna filosofiia XX stolittia. Kyiv: Dovira.

4. Kotler, F. (1999). Marketing-menedzhment: analiz, planirovanie, vnedrenie, kontrol. Sankt-Peterburg: Piter.

5. Kryvenko, K., Bieliaiev, O., Savchuk, V., Fuks, A., Malyi, I., Melnyk, O. ... \& Pohorielov, S. (2003). Politychna ekonomiia. Kyiv: KNEU.

6. Kulyutkin, Yu., \& Sukhobskaya, G. (Eds.). (1972). Motivatsiya poznavatelnoy deyatelnosti uchashihsya. Leningrad: NII OOV. Moskva: URSS.

7. Lapin, N. (2003). Sotsialnaya informatika: osnovy, metody, perspektivy. (2-e izd.).

8. Luman, N. (2005). Media-kommunikacii. Moskva: Logos.

9. Maslou, A. (1998). Motivaciya i lichnost. Sankt-Peterburg: Piter.

10. Mazurkiewicz, G. (2009). Adult educators: an example of the new approach to lifelong learning in Poland. European Journal of Education, 44 (2), 243-255.

11. Marriam, Sh. B., \& Brockett, R. G. (2007). The profession and practice of adult education. San Francisco, CA: Jossey-Bass. 